\title{
THE STRUCTURE
} OF SUB-NATIONAL PUBLIC DEBT: LIQUIDITY VS CREDIT RISKS

Javier J. Perez and Rocio prieto

Documentos de Trabajo N. 1403

\section{baneo gespaña}

\author{
Eurosistema
}


THE STRUCTURE OF SUB-NATIONAL PUBLIC DEBT:

LIQUIDITY VS CREDIT RISKS 
THE STRUCTURE OF SUB-NATIONAL PUBLIC DEBT:

LIQUIDITY VS CREDIT RISKS

\author{
Javier J. Pérez and Rocío Prieto
}

BANCO DE ESPAÑA

(*) The views expressed in this paper are the authors' and do not necessarily reflect those of the Banco de España or the Eurosystem. We are grateful to participants at the National Bank of Romania/ESCB WGPF Workshop (Bucharest, June 2013), the EcoMod2013 Conference (Prague, July 2013), and the seminar at the Banco de España (July 2013), in particular Claudia Braz, André Kolodziejak, Christopher F. Baum, Amela Hubic, Ang Roesch, Harald Schmidbauer and Ernesto Villanueva, along with as a referee of the Banco de España WP Series, for their useful comments. We also thank Jorge Abad, Luis Gordo, José A. Jiménez, Antonio Casado and José Pina for their help with the data. Correspondence to: Javier J. Pérez (javierperez@bde.es), Servicio de Estudios, Banco de España, c/Alcalá 48, 28014 Madrid, Spain. 
The Working Paper Series seeks to disseminate original research in economics and finance. All papers have been anonymously refereed. By publishing these papers, the Banco de España aims to contribute to economic analysis and, in particular, to knowledge of the Spanish economy and its international environment.

The opinions and analyses in the Working Paper Series are the responsibility of the authors and, therefore, do not necessarily coincide with those of the Banco de España or the Eurosystem.

The Banco de España disseminates its main reports and most of its publications via the INTERNET at the following website: http://www.bde.es.

Reproduction for educational and non-commercial purposes is permitted provided that the source is acknowledged.

C BANCO DE ESPAÑA, Madrid, 2014

ISSN: 1579-8666 (on line) 


\section{Abstract}

We analyse the determinants of the structure of public debt in the case of Spain, from a sub-national perspective. The endogenous shift in the composition of debt (among shortvs long-term instruments, and loans vs securities) depends on observable measures of credit and liquidity risks. To discriminate among competing potential determinants, we set out empirical models that incorporate financial, economic and institutional variables. We estimate the models by GMM and make use of a new quarterly dataset of Spanish regional governments' debt structure for the period 1995Q1-2012Q4. Our results show that the most robust determinants of regional public financial management decisions, as reflected by the structure of debt, are rollover risks and the expectation of central government support (as measured by the dynamics of transfers).

Keywords: sub-sovereign public debt, public financial management, public debt structure, financial vulnerability indicators.

JEL classification: H6; E62; C53. 


\section{Resumen}

Analizamos los determinantes de la estructura de la deuda pública en el caso de España, desde una perspectiva subnacional. El cambio endógeno en la estructura de la deuda (entre instrumentos de corto plazo e instrumentos de largo plazo, y entre préstamos y valores) depende de medidas observables de riesgo crediticio y de liquidez. Para discriminar entre los determinantes potenciales, diseñamos modelos empíricos que incorporan variables financieras, económicas e institucionales. Estimamos los modelos mediante el Método Generalizado de Momentos y hacemos uso de una nueva base de datos trimestral sobre la estructura de la deuda pública regional española para el período I TR 1995-IV TR 2012. Nuestros resultados muestran que los determinantes más robustos de las decisiones sobre la gestión de deuda pública regional, reflejada por la estructura de la deuda, son los riesgos de refinanciación y la expectativa del apoyo del Gobierno central (medido por la dinámica de las transferencias a las Comunidades Autónomas).

Palabras clave: deuda pública subsoberana, gestión pública financiera, estructura de la deuda pública, indicadores de vulnerabilidad fiscal.

Códigos JEL: H6; E62; C53. 


\section{Introduction}

The level of public debt in Spain more than doubled in the 2007-2012 period to reach 84.2 percent of GDP, almost closing the gap with the euro area aggregate number $190.7 \%$ in 2012), even though in 2007 the Spanish public debt-to-GDP ratio was 30 percentage points of GDP below the euro area one. ${ }^{1}$ Both central and sub-national governments suffered this surge in debt, leading particularly the latter to substantial pressure when issuing new debt and refinancing operations on maturing debt, both from the point of view of market access problems and increased costs. Thus, a great deal of attention has been paid recently to the determinants of the level of sub-central governments' debt. ${ }^{2}$ Sub-national fiscal imbalances have been signalled as a factor to be closely monitored given their potential to generate negative spillovers to overall Spanish public finances (Romeu, 2013, Fernández-Caballero et al., 2012). ${ }^{3}$ Indeed, as claimed by van Heck (2013), Spain's sovereign yields were contaminated in 2012 by the debt problems of its Autonomous Communities. Given the existence of spillover effects among debt markets of euro area peripheral countries (Caporale and Girardi, 2013) these risks stemming from regions in one country could become euro-wide risks.

Beyond the level of debt, its financing method and the resulting debt structure are much less explored factors underlying sub-national governments' solvency, even though they have been signalled to impinge on fiscal and macroeconomic outcomes. ${ }^{4}$ A perfectly solvent government -from the point of view of the standard debt sustainability analysis- may become insolvent due to short-run liquidity pressures. In fact, debt financing strategies can influence the exposure of a given level of government to short-term liquidity pressures. Therefore, this structure should be designed in such a way as to mitigate risks both for governments and for markets. Beyond the maturity structure, a related issue is the choice between the type

\footnotetext{
${ }^{1}$ For a descriptive analysis of debt developments in Spain since the inception of the recent crisis see Gordo et al. (2013). The source of public debt data throughout the paper is the Bank of Spain.

${ }^{2}$ See Argimón and Hernández de Cos (2012), Hernández de Cos and Pérez (2013), and the references quoted therein.

${ }^{3}$ On more general grounds, see also Ahmad et al. (2005).

${ }^{4}$ See e.g. Bacchiocchi and Missale (2005), Faraglia et al. (2008), Alfaro and Kanczuk (2009), Arellano and Ramanarayanan (2012), or Hatchondo and Martínez (2013). Empirical applications and calibrations of theoretical models tend to focus on emerging economies.
} 
of instrument used to cover financing needs, e.g. between loans and securities. Financing maturing debt and deficits by issuing securities tends to be more complicated in situations in which the liquidity risk is high, and typically loans offer an easier alternative. In the case of regional governments in Spain, in addition, loans provided by regional banks (savings banks, "Cajas de Ahorros") might have been perceived in the pre-crisis period as arising from a relatively safe ("captive") market as these regional banks were controlled to a large extent by regional governments.

The focus of our paper is on understanding the economic, financial and institutional determinants of the structure of sub-national ${ }^{5}$ public debt in the case of Spain, by analyzing a comprehensive database for the period 1995-2012. We deem the purpose of the paper a relevant one from a general point of view for a number of reasons. First, from the public financial management point of view, policy makers may find it instructive to explicitly know the covariates that de facto determine the observed structure of public debt. ${ }^{6}$ Second, as regards the interest from a financial point of view, Spain is the sixth sub-sovereign bond issuer world-wide, after the US, Germany, Japan, China and Canada (see Canuto and Liu, 2010). In the fourth quarter of 2012 total outstanding regional and local public debt amounted to 18.5 bn euro (17.6\% of Spanish GDP), of which some two-thirds were in the form of securities (other than shares). Third, from the point of view of fiscal federalism, Spain is currently one of the most decentralized countries in the European Union, after three decades of a continued and strong public revenue and expenditure devolution process, a period in which, in addition, a number of supranational and national fiscal rules were put in place in the country. Finally, in this paper we exploit a newly available quarterly dataset on the structure of regional government's debt. ${ }^{7}$

More in particular, we look at the determinants of the relative stock of debt at each maturity/instrument. If public debt managers were to have in mind a relative target value for each type of debt instrument, this would be, to our mind, the right type of object to study.

\footnotetext{
${ }^{5}$ Throughout the paper we will use the term sub-national to refer to Regional (Autonomous Communities).

${ }^{6}$ On related grounds, Moldogaziev and Luby (2012) analyze the covariates associated with the decision to refinance existing debt in the case of California state and local government issuers between 2000 and 2007.

${ }^{7}$ Since September 2012 the Bank of Spain disseminates on a regular basis and at the quarterly frequency information on the structure of Regional and Local governments' debt, for the period starting in 1995 Q1.
} 
Debt managers define an issuance policy (flow) with certain values of the stocks in mind, and departures from these target ratios only occur gradually, i.e. the selected ratios display strong inertia. This is what we observe in the data. In addition, the theoretical literature would support such a view. Beyond this general argumentation, data limitations prevent the scrutiny of issuance policies as such. Data in this regard could be mainly collected for securities other than shares.

The rest of the paper is organized as follows. In Section 2 we pose the main empirical hypotheses to be tested, against the background of existing theoretical and empirical work. In turn, in Section 3, we present some descriptive evidence on the structure of sub-sovereign public debt in Spain. Then, in Section 4, we describe the specific variables used in the empirical analysis as well as the econometric approach, while in Section 5 we present and discuss the main results of our study. Finally, in Section 6 we provide some conclusions and policy messages.

\section{Theoretical background and hypotheses to be tested}

\subsection{Theoretical background}

Some empirical studies have analyzed the determination of short-term debt, mainly in emerging market economies (Mehl and Reynaud, 2010; Valev, 2006, 2007; Lee et al., 2011; Borensztein et al., 2004; Rodrick and Velasco, 1999; Bussière and Mulder, 1999; Baldacci et al., 2011; Jedrzejowicz and Kozinski, 2012), some of them focusing on its role as an indicator of vulnerability to international financial crises. Increased reliance on short-term debt may make a government more vulnerable in a crisis framework, because of the need to rollover increased amounts of debt. As signalled by Borensztein et al. (2004), in a case in which a debt crisis mixes elements of illiquidity and insolvency, the government would be vulnerable to a piece of bad news, whose real impact would be amplified by creditors' unwillingness to roll over their claims (see also Jeanne, 2004). In addition, short-term debt can introduce another level of vulnerability for the fiscal accounts given that in an increasing interest rate environment interest payments may increase faster the higher the fraction of short-to-long- 
term debt. In this respect, the structure of public debt may become a channel or source of vulnerability to the real economy and the financial system (Das et al., 2010).

The structure of government debt is to be expected to change in the face of an economic and financial crisis, even in a situation in which market access were not compromised. First, because short-term instruments might be the only ones available to keep on covering financing needs. Indeed, investors might be willing to hold short-term debt even in a situation in which they assign a non-zero probability to default as they may expect the sub-central government to repay them before the eventual default takes place. Second, in the case of sub-central governments' debt, investors may expect that the central government bails-out the administration under pressure, thus assigning to the default option a low probability. In the case of Spain some studies suggest that there have been de facto bail-outs of regions by the center over the past decades (see Lago-Peñas, 2005; Sorribas, 2012). This is in line with the so-called "soft budget constraint problem" in intergovernmental fiscal relations, that arises when sub-national governments' spending and borrowing decisions are influenced by the expectation of receiving additional resources from the central government (see Vigneault, 2007, for a survey on this issue).

Third, as Missale et al. (1997) and Campbell (1995) argue, a government committed to fiscal consolidation and debt stabilization may reduce the cost of debt servicing by issuing short-term debt. This is the case in a framework of asymmetric information in which the government and private investors do not share the same information (or perception) and thus long-term debt instruments pay too high interest rates as a reflection of credibility problems. A government can thus issue short-term debt to signal its resolution to carry out its fiscal consolidation plans.

This discussion on vulnerability risks in the domain of the studies that look at the determinants of the structure of sovereign debt can be enriched by considering the broader literature that looks at the determination of corporate debt maturities ${ }^{8}$. The later literature exploits the trade-off between, on the one hand, liquidity risk considerations, which lead to a longer maturity choice, and, on the other hand, borrowers' preference for short-term debt due to private information about future credit rating. In his traditional liquidity risk

\footnotetext{
${ }^{8}$ See Berlin (2006) for a survey of this literature.
} 
hypothesis Diamond $(1991,1993)$ argues that short-term debt creates liquidity risk to the borrower because the lender may refuse to rollover the debt if a piece of bad news arrives. Nonetheless, firms with favorable private information would prefer short-term debt to benefit from refinancing on favorable terms when their true credit quality is revealed to the market at the time of refinancing, while firms with unfavorable private information about future default risk will prefer long-term debt and thereby eliminate the uncertainty about the future refinancing risk. Nevertheless, even in the case of having favorable projections, a given highly-rated borrower may decide to choose long-term debt if liquidity risks are perceived as high. Additionally, because of information asymmetry and extreme adverse selection cost, the firms with very poor credit rating are not able to borrow long-term debt and may have no option but to choose short-term debt. Therefore, as Diamond predicts, both very lowrisk and very high-risk firms would use short-term debt. These theoretical prediction of a non-monotonic relationship between debt maturity and liquidity risk has been tested and validated by a wealth of empirical research (see e.g. Barclay and Smith, 1995; Guedes and Opler, 1996; Stohs and Mauer, 1996; Johnson, 1997, 2003; Faulkender and Petersen, 2006): high- and low-ranked firms tend to issue short-term debt, while medium-ranked firms tend to rely on long-term debt.

This theoretical framework on the trade-off between the choice of the maturity of debt and liquidity risks can be instrumental to analyze the problem at hand in our paper. The discussed theories will therefore guide the selection of the variables to be included in the empirical analysis, as discussed in a subsequent section.

\subsection{Hypotheses to be tested}

Against the background of the previous discussion, we pose in our study a number of headline hypotheses to be tested:

- $H_{1}$ (Liquidity risks): Liquidity risks (proxied by roll-over risks) are expected to increase the fraction of short-term debt. In order to minimize liquidity risks, a given government would pursue long-term debt issuance. Nevertheless, if roll-over risks are high it would be the case that the government may only be able to issue short-term debt, and as such a positive and significant sign is to be expected. 
- $\mathrm{H}_{2}$ (Signalling): Signalling concerns (via "quality signals" such as adherence to fiscal targets) are expected to lead to a bias towards short-term debt vs long-term debt. A government would try to get short-term debt if current interest rates on long-term debt are high and the government intends to push for fiscal discipline. If fiscal discipline leads to credibility gains in the future, it would be possible for the government to issue long-term debt in more favorable conditions than currently.

- $H_{2}^{b}$ (Signalling and the fraction of loans vs securities): It is expected that a higher perceived quality of a given government may lead to an increase in the fraction of securities vs loans, as a better access to the international markets may be granted.

- $H_{3}$ (No bail-out and short- vs long-term debt): If investors perceive a strong support of the Central Government, they would be willing to take long-term government debt. Investors may assign a high probability to the bail-out option of a given region by the Central Government, and thus a low probability to the default alternative. As a consequence, investors would be willing to get long-term debt given favorable interest rates and Central Government implicit guarantees. Thus, CG support may help easing access to the markets by regions, while at the same time may induce that too high interest rates are locked-in today for the future (i.e. until the redemption of a given issuance of long-run debt).

- $H_{4}$ (Business cycles): In adverse cyclical conditions and under market stress, there might be a shift towards shorter-term instruments and loans vs securities, while at the same time an increase in the fraction of resident holders is expected.

\section{Some stylized facts}

Our panel contains quarterly data for each individual regional government, covering the period 1995Q1-2012Q4. In this Section we provide some stylized facts on the main relevant aggregates of the 17 Spanish regions. The recent crisis period has led to a substantial increase in sub-national debt in Spain. This is not a phenomena restricted to these levels of the government sector in Spain, but rather a general fact, as witnessed in Figure 1. 
In the particular case of regional governments, their aggregated debt increased from some $5.8 \%$ of GDP in 2007Q4 to $13.3 \%$ in 2011Q4 and further to $17.6 \%$ at the end of 2012 (see Table 1). In 2012, 3.3 points of GDP of this debt were in the form of loans provided by the Central Government, that put in place along the year a number of programmes to support regional governments subject to liquidity problems. In particular, since early 2012, the Spanish government implemented two types of financial support funds. First, the so-called, "Fund for the Financing of Providers" (Fondo para la Financiación del Pago a Proveedores, FFPP) that aimed at paying down commercial debts ("Other accounts payable by the government sector", in particular, trade credits) of regional and local governments with non-financial corporations. The later had escalated to some 4\% of GDP in 2012Q1. As of 2012Q4, some $65 \%$ of the latter amount had been payed (some 27 bn euro), while the remaining amounts were payed by the end of 2013 (indeed, as of December 2013 the central government took care of paying down approximately 42 bn euro in cumulative terms since 2012Q1). A second financial support plan was the "Regional Liquidity Fund" (Fondo de Liquidez Autnómica, FLA), implemented by mid-2012, that was initially designed to cope with the debt refinancing needs of regional governments. In 2012, the FLA lent a total of 16.6 bn (1.6\% of GDP) to regional governments that joined the mechanism (see Gordo et al. (2013) for more details on these issues).

If instead of using GDP we use regional governments' total revenues ${ }^{9}$ as the denominator of the ratio to their public debt, the picture that emerges is noteworthy and gives an idea of the level of financial stress regions have been subject to. Indeed, in 2007Q4 debt was less than $40 \%$ of their revenues, after decreasing steadily over the 1990s and 2000s also on the back of a strong devolution process, but it more than tripled since then to reach some $126 \%$ in $2012 \mathrm{Q} 4$.

The increase in the level of sub-national debt witnessed in Spain in the crisis period came hand-in-hand with a change of its structure. First, the ratio of short- to long-term debt ${ }^{10}$

\footnotetext{
${ }^{9}$ Total non-financial revenues, including transfers from other levels of the General Government.

${ }^{10}$ The measure available for long- and short-term debt is the sum of total Securities other than shares and Loans by Resident Financial Institutions. To our knowledge, there is currently no comprehensive dataset publicly available on the short- versus long-term distribution of regional governments' loans by the Rest of the World.
} 
stood at $11 \%$ in $2007 \mathrm{Q} 4$, down from the $33 \%$ of the beginning of the sample (1995), but increased substantially to close to $25 \%$ by 2011Q4 at the height of the euro area sovereign crisis (see Figure 2). The same picture can be drawn from the data by region. This change in structure occurred, in parallel to an increase in the amount of maturing debt by year, as shown in Figure 3 (upper panels), where we show the ratio of short- to long-term debt versus the amount of financing needs (as a percent of each region's GDP). In 2012 the fraction of short- to long-term debt got reduced to levels similar to the ones observed at the beginning of the crisis, but still well above pre-crisis values.

The second change witnessed in the structure of regional debt has to do with the portfolio of securities vs loans. Traditionally, sub-central governments in Spain have relied more intensively on loans than the Central Government. Regional governments managed to increase in a steadily manner the ratio of securities-to-loans from some $66 \%$ around 1995 to above $105 \%$ by 2007. Since then, the upward trend has been reversed, and in 2012Q4 the stock of regional debt was distributed by almost half between securities and loans. Nevertheless, the relative ratio for 2012 is significantly affected by the fact that a number of financial funds implemented in the course of the year by the Central Government aimed at easing Regional governments' difficulties in accessing the markets were accounted for as loans; excluding the latter factor, the ratio of securities to loans stood at close to $75 \%$ in 2012Q4. It is worth noting that support funds were aimed particularly at the more troubled regions (see Figure 4), typically those with a high amount of financing needs and/or high levels of debt.

It is also possible to scrutinize the distribution of regional debt by resident financial institutions and non-resident holders ("Rest of the World"), but only in the case of loans due to data limitations. In this regard, the ratio of loans by non-residents to loans by resident financial institutions decreased by half in the crisis period, after having reached more than $100 \%$ in 2007.

Finally, as shown in Figure 5 for the case of regional debt, the discussed debt-structure ratios - namely, the ratio of short-term to long-term debt, the ratio of loans to securities, and 
the ratio of loans by residents to those by non-residents - showed positive (unconditional) correlations over the period 1995-2012, with implicit interest rates on overall regional debt. ${ }^{11}$

Summing up, in the pre-crisis period the structure of regional governments' debt was sound according to the usual standards in the "sovereign debt vulnerability" literature. The ratio of short- to long-term debt was at historical lows, the ratio of securities to loans at historical highs, and there was a broad base of non-resident operators in the loans segment of the market. Nevertheless, the impact of the crisis moved all these ratios in the direction that economic theory would have predicted.

\section{Variables and empirical approach}

\subsection{Variables of interest}

As regards the ratio of short- to long-term debt, $B_{t}^{S T} / B_{t}^{L T}$, both the numerator and the denominator are constructed as the sum of securities other than shares and loans by resident financial institutions, at the corresponding maturity. Thus, both the numerator and the denominator exclude loans by non residents given lack of data on its decomposition by maturity. In addition, it is worth highlighting that loans by the central government are excluded from this definition to avoid distortions in the subsequent analysis. This is a phenomena confined to the year 2012, given that the central government support funds to the regions mentioned in a previous section were implemented through loans. The first ratio of interest captures the relative preference over the maturity of debt. The second ratio of interest is the one of securities to loans, $B_{t}^{S} /\left[B_{t}^{L}-B_{t}^{C G, L}\right]$, where again exceptional Central Government liquidity-support funds in 2012 are excluded.

\footnotetext{
${ }^{11}$ The source of interest payments' data is the IGAE. Implicit interest rates are computed as the ratio of interest payments to overall debt and are only available at the annual frequency for the period under study.
} 


\subsection{Control variables}

Liquidity risks We proxy "liquidity risks" by a variable measuring "roll-over risks" ( $F i$ nancing needs), defined as maturing debt in the period ${ }^{12}$ plus deficit financing needs ${ }^{13}$.

Economic factors GDP growth is typically used as a proxy to measure current cyclical conditions, but also future potential growth. In economic recessions, budget deficits increase and so public debt does. At the same time, the economic environment may affect the ability of a government to place its debt in the market. When the economy is in a downturn, the market becomes more restrictive and confidence levels decrease, which may entail lenders preference for shorter maturities and safer bonds (De Broeck and Guscina, 2011; Goudswaard, 1990). As a proxy to the business cycle we take the Industrial Production Index (IPI) given the lack of quarterly GDP data ${ }^{14}$. IPI is a widely used measure in the literature analyzing business cycles, and has been shown to be of use in the case of the Spanish regions (see Gadea et al., 2013). We take the annual growth rate of IPI (Cycle).

In addition to a measure of economic activity, the literature highlights the importance of price inflation (we use CPI annual growth data, Inflation). A positive relationship between inflation and the short- to long-term debt ratio is expected: one can expect that the higher interest rates that increasing prices imply would make shorter maturities more attractive to bond takers (Goudswaard, 1990). Inflation reduction or stabilization may also be seen as a signal of monetary credibility which will affect debt composition towards safer structures. For example Mehl and Reynaud (2010) show that the share of short-term debt in total public debt decreases when inflation declines. Higher inflation is associated with higher inflation uncertainty, leading to higher risk premia on long-term nominal debt and thus leading governments to stop issuing long-term debt (Missale and Blanchard, 1994). Hoogduin, Ozturk and Wierts (2010) show that in an inflationary environment, investors might opt for short

\footnotetext{
${ }^{12}$ The source of data on maturing debt is the Bank of Spain. It comprises maturing securities.

${ }^{13}$ There are no quarterly regional government deficit figures available for the period 1995-2010. For this period the annual deficit is taken and distributed among the four quarters of each year on the basis of the profile of the general government figures.

${ }^{14}$ The Spanish National Statistical Institute publishes raw IPI figures for all the Spanish regions. We seasonally-adjusted the raw series using the TRAMO-SEATS package.
} 
term positions. They found that higher inflation increases the share of short term financing. In our application with regional data, though, these considerations might not be relevant because of the different scope of the analysis (regions vs countries) and because almost all debt issued in the past decades was debt in euros within a broad monetary union.

Size of the issuer The size of the Region (Size) is expected to be positively related to debt maturity. In this sense, wealthier/larger regions are presumed to enjoy easier access to markets and a greater ability to issue safer debt. However, and, at the same time, because of that wider market access for the region, shorter debt instruments are also expected to be more used. We measure this economic concept by the relative GDP of the region compared to the nation-wide one. ${ }^{15}$

Signalling hypothesis: quality Debt maturity is and appropriate and valid signal to asymmetrically informed markets about the quality of a firm (Myers, 1977; Leland and Pyke, 1997; Ross, 1997) or a government. Lower debt maturities in the literature looking at the debt maturity choice tends to be associated with a higher quality of the issuer. In the case of sovereign issuers, the fulfilment of budgetary objectives can be considered as a signal of high quality, in particular in times of fiscal consolidation (Budgetary deviation). In the same fashion, additional measures might be the level of debt of the region $(D e b t / G D P)$, its relative debt compared to peers (Debt deviation), the change in debt and any interaction of these variables. Missale and Blanchard (1994) show that governments will tend to have a shorter debt maturity to enhance credibility when the debt burden is high, but not necessarily at low levels. Hoogduin et al. (2010) state that a higher debt stock may also signal higher credit risk and limit access to the capital market. They found that higher debt seems to lead to a more "prudent" financing. World Bank (2005) argues that fiscal consolidation is a key component of a credible debt reduction strategy. De Broeck and Guscina (2011) signal that higher debt has a non-linear effect on the domestic medium-to-long term debt with a fixed interest rate shares: debt has to achieve a critical mass for liquidity purposes and generate institutional investor interest. However, once the debt (as a share of GDP) exceeds a certain

\footnotetext{
${ }^{15}$ To compute the quarterly ratios, quarterly regional GDPs have been interpolated on the basis of each region's share in annual overall Spanish GDP.
} 
threshold, sovereign risk is a concern and medium-term instruments are less attractive for investors. Guscina (2008) shows that more heavily indebted countries (as proxied by debt service to GDP ratio) have problems extending the maturity profile of domestic debt.

Finally, we also computed a standard sustainability indicator, namely European Commission's $\mathrm{S} 1$ indicator, to use it as a proxy of the quality of public finances in the medium-term. The S1 indicator shows the durable adjustment to the structural primary government balance required to reach a target public debt of $60 \%$ of GDP in 2060 . The indicators quantify the gap that must be closed to ensure the sustainability of public finances. The larger the value of the gap indicator, the greater is the necessary adjustment to the structural primary balance to ensure sustainability. To compute this indicator for each quarter of the period 1995Q1 to 2012Q4, one needs assumptions about the future evolution of the variables that enter the intertemporal government budget constraint, namely real GDP growth, the nominal interest rate, the inflation rate, public debt and the primary budget balance. First, we take observed values of the variables as the expected values (perfect foresight hypothesis) when possible. Second, we use the forecasts of the latest Spanish Stability and Growth Pact of April 2013 for the period 2013-2016. Finally, to extrapolate beyond 2016 we follow the somewhat standard practice of keeping the necessary variables constant, i.e. equal to the 2016 projected value.

Term structure A positive relation is expected between debt maturity and the term structure (see for example Brick and Ravid, 1985) as investors certainly weigh the relative costs of alternative debt instruments. We use a measure of the slope of the yield curve (Slope): the average yield in a given quarter of the 10-year Spanish bond minus the equivalent measure of the 6-month T-bill.

Market preferences Market preferences on overall Spanish government debt instruments could influence the structure of regional public debt. Market conditions could be measured by the extent to which governments are able to issue all the debt they intend to. For this purpose, we use the ratio of central government bonds and Treasury Bills allocations to requests (Bonds coverage). As this ratio is closer to one, the room for implementing debt 
issuance strategies by the government diminishes. Therefore, we expect this variable to have a positive sign on the short-to-long regional debt ratio.

Another side of the preference equation is the presence of foreign investors in the market for regional debt. A higher presence of foreign investors (risk-averse) may lead to shorter maturities. Mehl and Reynaud (2008) state that a broader domestic investor base (ratio of gross private savings to GDP) can be expected to make domestic debt composition safer by contributing to support demand for (domestic currency, unindexed) long-dated debt instruments. To avoid endogeneity problems we build up a variable, $N R / R$ preference to, be included as a regressor in the equations determining the ratios of interest (short-to-long and securities-to-loans) and that, as will become clearer in the next Section, is the residual of a regression of the ratio of non-resident-to-resident loan providers on all the explanatory variables included in each equation.

Other controls: political and institutional factors The literature has proved that institutional and political factors need to be taken into account when fiscal performance is analyzed. On the one hand, we incorporate electoral variables (Elections dates). This relates to the evidence proving that as elections are closer governments tend to increase expenditures in an attempt to show voters they care about welfare and social matters. This may therefore influence debt patterns and we are interested in testing whether this affects the debt structure itself or favors any of the issuance strategies considered. More specifically, Elections dates is a regional dummy that takes the value 1 in a particular quarter if a regional election took place in that very quarter. ${ }^{16}$

Additionally, there is an existing literature that focuses on whether the quality of institutions influences public debt management. Guscina (2008) states that better institutions decrease the share of short-term debt. Weak institutions can compromise the government's ability to implement effective fiscal policy, to constrain policy commitments, to manage liabilities and to control and limit fiscal risk. Nevertheless, the existence of fiscal and no-bailout

\footnotetext{
${ }^{16}$ We also tried in the empirical models another proxy to test for electoral cycles: Proximity to elections, that is an indicator that takes the timing of an election into account. We use the version of the latter developed by Franzese (2000), that is calculated as $E L E C_{i t}=[(M-1)+d / D] / 12$, where $M$ is the month of the election, $d$ the day of the election and $D$ is the number of days in that quarter.
} 
rules may exert some influence on moving market preference to shorter bonds. According to Borensztein et al. (2004) lack of credibility plays an especially important role in periods leading up to crises, as governments tend to shift the composition of their debt towards shorter maturities and foreign-currency denomination. In turn, Valev (2006) finds that weak institutions explain why some countries find it difficult to obtain lon-term financing. We use EC's Fiscal Rule Index (FRI) in our empirical analysis to test the effect of formal rules on the variables of interest. The $F R I$ is a comprehensive time-varying fiscal rule index constructed by the European Commission for each EU Member State. Each individual fiscal rule is weighted by the coverage of general government finances of the respective rule (i.e. public expenditure of the government sub-sector(s) concerned by the rule over total general government expenditure); in the presence of more than one rule covering the same government sub-sector, the second, third, and fourth rules obtain weights $\frac{1}{2}$, $\frac{1}{3}$ and $\frac{1}{4}$, to reflect decreasing marginal benefit of multiple rules applying to the same sub-sector. The assigned weights are mainly determined by the fiscal strength of the rule and its coverage.

The territorial organization of a country has also been pointed out by the literature as a determinant of the fiscal situation. Particularly, the increasing responsibilities assumed by the regions and the available instruments for their funding are factors that influence fiscal outcomes and then public debt patterns. Following this idea, an indicator of fiscal co-responsibility (Corring) has been introduced in our analysis. The index is constructed as the ratio of taxes on which regions have normative power (direct ${ }^{17}$ and indirect taxes ${ }^{18}$, excluding VAT) to total revenues. To ease changes in expenditures responsibilities in the middle of the sample, we split it into two variables which take the value of the mentioned indicator for the corresponding period (1997-2001 and 2002-2010, respectively ${ }^{19}$ ) and zero otherwise (Fiscal corresponsibility 1997-2001 and Fiscal corresponsibility 2002-2010). We expect these two variables to have a negative impact on the short- to long-term debt ratio as increasing fiscal responsibility is thought to have led to reductions in systematic debt issuance and possibly disfavor short-term bonds. Additionally, given the different pace of revenue and expenditure devolution in Spain over the past three decades, we also incorporate

\footnotetext{
${ }^{17}$ Namely, Inheritance tax, Income tax, Wealth tax, and others.

${ }^{18}$ Namely, Property Transfer and Certified Legal Documents Tax, Excise Duties, and others.

${ }^{19}$ See Hernández de Cos and Pérez (2013) for more details on this issue.
} 
a measure of public expenditure responsibilities. It is worth mentioning that education and health expenditure is almost fully a responsibility of regional governments. Given shortages of data we were only able to compute a measure of health expenditure (Health expenditure).

Beyond the latter measures of "fiscal decentralization", a key variable to incorporate in the analysis is the amount of Central Government transfers ( $C G$ transfers) to the regions. This is so because of the existence of evidence on the "soft-budget constraint" hypothesis discussed above. To control for changes in the form of regional financing, we construct an aggregate measure (i.e. for the aggregate of regional governments) that sums shared taxes (that started to be devolved at increasing speed as of the end of the 1990s) and genuine Central Government transfers to the regions.

\subsection{Empirical strategy}

The econometric model used can be specified in general terms as

$$
Y_{i t}=\alpha_{i}+\sum_{j=1}^{N} \beta_{j} \Omega_{j i t}+\sum_{j=1}^{N} \gamma_{j} X_{j i t}+\epsilon_{j i t}
$$

Where the particular debt structure ratio for each Regional government $i$ at time $t, Y_{i t}$, depends on two sets of control variables, $\Omega$ and $X$, encompassing all factors mentioned above. The first set, $\Omega$, contains the lagged dependent variable along with potential endogenous controls, which will be modeled differently from those comprised in $X$, which are thought to be exogenous. We follow the traditional fixed-effects model approach, where $\alpha_{i}$ aims at capturing all the unobservable region-specific effects that are time-unvarying, while $\epsilon_{i t}$ is an error term assumed to be a white noise. In order to control for potential correlation between individual effects and regressors, we estimate equation (1) in first differences. This, however, does not avoid latent simultaneity problems that may arise between regressors and the lagged error term $\epsilon_{i t-1}$. Besides, the lagged dependent variable, $Y_{i t-1}$, still remains potentially endogenous. For these reasons, the estimation is carried out by the Generalized Method of Moments (GMM). Particularly, we perform GMM estimations instead of difference GMM since lagged levels could be poor instruments for first differences if the variables are close to a random walk. In practice, we implement the Stata routine xtabond2, which, along 
with the estimation of the model equation (1) in first differences (transformed equation), adds to the system the original equation in levels (untransformed equation) so additional instruments can be brought to increase efficiency. In a first step, differenced variables in (transformed) equation (1) are instrumented with their own available lagged levels. Then, level variables in (untransformed) equation (1) are instrumented with suitable lags of their own first differences. ${ }^{20}$

In our framework, most of the variables included in the analysis are potentially endogenous. In fact, in our empirical models all the potential covariates discussed in the previous Section are considered to be part of $\Omega$, with the exception of the variables measuring the institutional strength of fiscal rules and electoral dates. In addition, as briefly discussed in the introductory and stylized facts sections, our dependent variables are quite persistent. Indeed, public debt managers tend to have in mind (either explicitly or implicitly) a relative target value for each type of debt instrument, a situation that to a large extent determines the issuance policy (flow), what creates a strong inertia in the observed equilibrium time series. Given the large amount of variables to be instrumented, we payed special attention to the number of lags used as instruments. We tried several specifications with one, two and more lags. On the one hand, the quarterly nature of our data advises the inclusion of more than one lag, also bearing in mind that more distant lags would qualify as better instruments. Nevertheless, on the other hand, the quality of the Hansen test of the instruments' joint validity deteriorates significantly with more than two lags, even though the quantitative results do not vary significantly, as shown in the next Section. The models with one and two lags are broadly appropriate (as it will be shown in the empirical results' Section) and do not differ significantly among them in qualitative and quantitative terms. Given the quarterly frequency of our dataset we show in the tables the results using two lags. ${ }^{21}$

Finally, even though it is known that in a framework like ours OLS estimators may suffer from the "dynamic panel bias" (the positive correlation between a regressor and the error violates an assumption necessary for the consistency of the OLS estimator), we also provide

\footnotetext{
${ }^{20}$ Arellano and Bover (1995), Roodman (2006).

${ }^{21}$ Detailed results using one and three lags are available from the authors upon request, and are not shown for the sake of simplicity. In the next Section we only show one selected set of results using different lags as instruments, for the sake of robustness.
} 
them in all the tables of results shown in the next Section. The reason is that one has to acknowledge that system GGM estimators in finite samples may be subject to instrument proliferation, and as such a simpler and more widely understood estimation alternative may be helpful for the informed reader.

\section{Results}

The main results of the paper are summarized in tables 2,3 , and 4 , where we present a subset of the results, that involved a larger number of empirical specifications that combined all the control variables described above. In the tables we show results for the full sample (1995Q1-2012Q4), for the pre-crisis sample (1995Q1-2007Q4) and for the sample excluding $2012 .{ }^{22}$

As regards the determinants of the ratio of short- to long-term debt, $B_{t}^{S T} / B_{t}^{L T}$, the following results are worth highlighting (tables 2 and 3 ).

First, the variable measuring roll-over risks (Financing needs) appear as the most robust regressor in all the specifications considered. An increase in the amount of financing needs (either in the form of maturing debt or current deficit financing) leads to a debt structure more leaned towards short-term debt, i.e. the amount of short-term debt increases in relative terms with respect to the amount of long-term debt. This result lends support to the view that increased liquidity risks imply a shortening of debt maturities, once the rest of variables included in the empirical specification are controlled for. The costs associated with shortterm debt (risk associated to potential difficulties to rollover the debt) are thus outweighed by other factors. This result holds for the whole sample and also for the pre-crisis sample (i.e. when the post-2007 sample is excluded from the estimation). In line with the theoretical priors laid out before, one may claim that this result is consistent with a situation in which Autonomous Communities, that presented a sharp reduction in their credit ratings since

\footnotetext{
${ }^{22}$ We show in the tables point estimates and their significance. Regarding statistical tests, we check for both autocorrelation and overidentifying restrictions. With respect to the former, the Arellano-Bond test is implemented. As regards the latter, given that the Sargan statistic is not robust to heteroskedasticity or autocorellation, for one-step robust estimation (and for all two-step estimation), only the Hansen J statistic is reported, which is the minimized value of the two-step GMM criterion function, and is robust.
} 
the inception of the crisis, were not able to borrow as much long-term debt as desired and may have no option but to choose short-term debt. From a different point of view, one may read this empirical evidence, according to a stream of the literature, from the angle that governments would have tried to reveal to the markets their solvency - reflected in the long-term fundamentals or the expectations of a central government bail-out - or their commitment to fiscal consolidation by issuing more short-term debt in relative terms, in an attempt to obtain refinancing in the near term on favorable terms when their true credit type is assessed by investors. On related grounds, and in order to rationalize the pre-crisis results, one may argue that governments facing a favorable stream of revenues (as in the pre-crisis period) would have preferred short-term debt to benefit from better refinancing conditions if this were taken by the market as a quality signal at the time of refinancing.

Second - still on the determinants of $B_{t}^{S T} / B_{t}^{L T}$ - the variable measuring Central Government transfers ( $C G$ transfers) appears also as a quite robust regressor across empirical specifications and samples. The negative sign denotes that investors anticipate that the Central Government would increase transferred resources (be it genuine transfers or improvements in the financing arrangements) in case a given region face financial problems, and thus they will be willing to finance longer-term debt to that particular region at favorable conditions for them. This is in line with the prescription of the "soft budget constraint" theory. The implicit bail-out that increased central government transfers might imply can be seen to the light of investors as a safeguard against the potential losses of a given regional government's default.

Third, the size of the region (Size), is significant and presents a positive sign. This is consistent with the standard result in the empirical literature that the size of a debt issuer is significant for market access, possibly because it implies a deeper debt market.

Fourth, stricter adherence to previous year's budgetary target (Budgetary deviation) tends to be associated with easier access to short-term debt in relative terms. This result would support the view outlined above that quality signals would be associated with a will to issuing more short-term debt in relative terms, in order to obtain more favorable refinancing conditions in the near future. Even presenting the expected negative sign, the estimates when only the pre-crisis sample is considered are less precise and thus the variable lose statistical significance. 
Fifth, the variable that measures preference for Spanish debt, measured by the slack in Treasury's auctions (Bonds coverage) is significant and presents the expected positive sign. Finally, the shock to the preference of non-resident debt holders $(N R / R \text { preference })^{23}$ has a negative sign, indicating that foreign investors' non-systematic behavior (not explained by fundamentals) is more favorable to longer maturities. This variable turns out to be only statistically significant when the crisis years are included in the estimation, as might have been expected.

A significant group of variables were not found to present statistical relevance for the determination of the ratio of short- to long-term debt. Among others, the variables measuring the business cycle influence, the long-term sustainability of public finances (S1) and those related to institutions and the political cycle variables. As a matter of fact, some of these variables (and other) are typically found in the literature to be explanatory factors of the level of public debt, which do not imply that they should have explanatory power on the structure of debt itself, in a framework in which different types of debt tended to move in similar directions.

Regarding the determinants of the ratio of Securities to Loans $\left(B_{t}^{S} /\left[B_{t}^{L}-B_{t}^{C G, L}\right]\right)$, that are displayed in Table 4, the following results can be underlined. First, as in the case of the maturity structure, the variable measuring financing needs shows up statistically significant. The negative sign, in this case, indicates that increased financing needs shifts the portfolio composition more towards loans, as expected. In times of financial hardship regional governments would tend to resort in relative terms more to loans. The reliance on loans could be expected given that this source of financing rests mainly on the (national/regional) banking sector and thus entails less trouble than open issuance in the market. This is clear in the case of Spain given that Autonomous Communities could rely over most of the sample period analyzed on regional, savings banks ("Cajas de Ahorros"). The particular governance structure of these entities, that involved significant regional government presence, may have facilitated the use of this channel of financing. Second, the expectation of Central

\footnotetext{
${ }^{23}$ Remember this is constructed by using the same specification as in the baseline equation but with the ratio of non-resident to resident loan providers.
} 
Government bail-out ( $C G$ transfers) is also statistically significant in the broader sample and presents a positive sign in all cases. This implies that central government support made it easier for regional governments to twist their portfolio, everything else being equal, towards securities, as it would have been expected. Nevertheless, when considering all the empirical specifications and samples, this regressor is less robust than in the case of the short- vs long-run ratio. Finally, the shock to the preference of non-resident debt holders $(N R / R$ preference $)$ presents a positive sign, indicating that foreign investors' non-systematic behavior (not explained by fundamentals) is more favorable to securities rather than loans in relative terms, also as expected. As for the rest of control variables, only the interaction of the level of debt with the deficit, among the indicators of "quality", turned out to be is statistically significant in a consistent way across specifications, presenting the expected negative sign.

Finally, as a matter of additional robustness check for the GMM estimator, we show in Table 5 the results obtained for the main empirical specifications for different number of lags used as instruments (1, 2, and 3 lags). The figures presented show that our main results are quite robust to this critical GMM issue.

\section{Conclusions}

We analyze the determinants of the structure of public debt in the case of Spain, from a sub-national perspective, focusing on the ratios of short- to long-term debt and, securities vs loans. We incorporate a number of variables that proxy liquidity and credit risks and assess their relative merit.

Our results can be summarized as follows, to the light of the hypothesis posed. As regards $H_{1}$ liquidity risks (proxied by roll-over risks) are found to increase the fraction of short- to long-term debt. Thus, the costs associated with short-term debt (potential difficulties to rollover the debt) are found to be outweighed by other considerations. In particular, one may rationalize this result given the potential inability of low-rated Autonomous Communities to have the desired access, in relative terms, to longer term instruments. From a different point of view, though, one may read this evidence to the light of one strand of the literature 
that states that fundamentally sound governments may be willing to issue in relative terms more short-term debt, in order to obtain refinancing in the near term on favorable terms when their true credit type is assessed by investors. As regards the impact of liquidity risks on the choice of securities vs loans, we find that increased financing needs shifts the portfolio composition more towards loans, as expected.

Regarding the signalling hypothesis $\left(H_{2}\right)$, we find only a reduced set of statistically significant determinants (budgetary deviations, size of issuer). In the cases in which the variables were significant we found that quality signals were conductive to a relative bias towards short-term debt vs long-term debt and securities vs loans.

Central government support is found to be consistent with some form of the "soft budget constraint hypothesis", namely that investors may be assigning a high probability to the bail-out option of a given region by the Central Government. As a consequence, investors would display a relative preference for holding longer-term debt, and securities.

Other factors play a much lower role in explaining the debt structure ratios of interest. In particular, institutional and political factors are not found to be of relevance in a robust manner across empirical specifications. This is also the case for the influence of the business cycle $\left(H_{4}\right)$.

\section{References}

Ahmad, E., M. Albino-Ward and R. Singh (2005), "Subnational public financial management: institutions and macroeconomic considerations", International Monetary Fund Working Paper WP/05/108.

Alfaro, L. and F. Kanczuk (2009), "Debt maturity: is long-term debt optimal", Review of International Economics, 17, pp. 890-905.

Arellano, C. and A. Ramanarayanan (2012), "Default and the maturity structure in sovereign bonds", Journal of Political Economy, 120, pp. 187-232.

Arellano, M. and O. Bover, (1995), "Another look at the instrumental-variable estimation of error- components models", Journal of Econometrics, 68, pp. 29-52. 
Argimón, I. and P. Hernández de Cos (2012), "Fiscal rules and federalism as determinants of budget performance: An empirical investigation for the Spanish Case", Public Finance Review 40, pp. 30-65.

Bacchiocchi, E. and A. Missale (2005), "Managing Debt Stability", CESifo, Working Paper No. 1388.

Baldacci, E., J. McHugh, I. Petrova (2011), "Measuring fiscal vulnerability and fiscal stress: a proposed set of indicators", IMF Working Paper.

Barclay, M. J. and Clifford, W. Smith (1995), "The Maturity Structure of Corporate Debt", The Journal of Finance, Volume 50, Issue 2, pp. 609-631, June 1995.

Berlin, M. (2006), "Debt maturity: what do economists say? What do CFOs say?", Business Review Q1 2006, Federal Reserve Bank of Philadelphia.

Borensztein, E., M. Chamon, O. Jeanne, P. Mauro and J. Zettelmeyer (2004), "Sovereign debt structure for crisis prevention", IMF Occasional Paper 237.

Brick I. E. and S. A. Ravid (1985), "On the Relevance of Debt Maturity Structure", The Journal of Finance, Volume 40, Issue 5, pp. 1423-1437, December 1985.

Bussiére, M. and C. Mulder (1999), "External vulnerability in emerging market economies: how high liquidity can offset weak fundamentals and the effects of contagion", IMF Working Paper No 99/88.

Campbell, J. Y. (1995), "Some lessons from the yield curve", Journal of Economic Perspectives, 9, pp. 129-152.

Canuto, O. and L. Liu. (2010), "Subnational debt finance: make it sustainable", Chapter in Otaviano Canuto and Marcelo Giugale, eds., The Day After Tomorrow - A Handbook on the Future of Economic Policy in the Developing World. 2010, World Bank, Washington, DC, pp. 219-237.

Caporale, G. M. ans A. Girardi (2013), "Fiscal spillovers in the Euro area", Journal of International Money and Finance, in press. 
Das, U. S., M. Papapioannou, G. Pedras, F. Ahmed, and J. Surti (2010), "Managing public debt and its financial stability implications", IMF Working Paper.

De Broeck, M. and A. Guscina, (2011), "Government Debt Issuance in the Euro Area: The Impact of the Financial Crisis", IMF, Working Paper 11/21.

Diamond, D.W, (1991), "Debt Maturity Structure and Liquidity Risk", The Quarterly Journal of Economics, Vol. 106, No. 3 (Aug., 1991), pp. 709-737.

Diamond, D.W, (1993), "Seniority and maturity of debt contracts", Journal of Financial Economics, Vol. 33, Issue 3, June 1993, pp. 341-368.

Faraglia, E., Marcet, A. and A. Scott (2008), "Fiscal Insurance and Debt Management in OECD Economies", The Economic Journal, 118, (March), pp. 363-386.

Faulkender M. and M. A. Petersen, (2005), "Does the Source of Capital Affect Capital Structure?", The Review of Financial Studies (Spring 2006), 19 (1): pp. 45-79.

Fernández-Caballero, L., D. J. Pedregal and J. J. P'erez (2012), "Monitoring sub-central government spending in Spain", Hacienda Pública Española / Review of Public Economics 202, pp. 77-104.

Gadea, M.D., Gómez-Loscos, A. and A. Montañés (2012), "Cycle inside cycles: Spanish regional aggregation", Journal of the Spanish Economic Association, SERIEs (2012), 3, pp. 423-456.

Gordo, L., Hernández de Cos, P. and J.J. Pérez (2013), "Developments in Spanish Public Debt since the start of the crisis", Economic Bulletin, Bank of Spain, July-August 2013.

Goudswaard, K.P. (1990), "Determinants of Public Debt Maturities", De Economist, 138, NR. 1, 1990, pp. 33-46.

Guedes, J. and T. Opler (1996), "The Determinants of the Maturity of Corporate Debt Issues", The Journal of Finance, Volume 51, Issue 5, pp. 1809-1833, December 1996. 
Guscina, A. (2008), "Impact of Macroeconomic, Political, and Institutional factors on the Structure of Government Debt in the Emerging Market Countries", IMF Working Paper WP/08/205.

Hatchondo, J. C. and L. Martínez (2013), "Sudden stops, time inconsistency, and the duration of sovereign debt", IMF Working Paper WP/13/174.

Hernández de Cos, P. and J. J. Pérez, (2013a), "The new Budgetary Stability Law", Bank of Spain Economic Bulletin, April 2013.

Hernández de Cos, P. and J. J. Pérez, (2013b), "Sub-national public debt in Spain: political economy issues and the role of fiscal rules and decentralization", pp. 188-216 in European Commission Economics Papers, 501, "Fiscal relations across government levels in times of crisis - making compatible fiscal decentralization and budgetary discipline".

Hoogduin, L., Öztürk, B. and P. Wierts (2010), "Public Debt Managers' Behaviour: Interactions with Macro Policies", De Nederlandsche Bank Working Paper No. 273/December 2010.

Jeanne, O. (2004), "Debt maturity and the International Financial Architecture", IMF Working Paper.

Jedrzejowicz, T. and W. Kozinski (2012), "A framework for fiscal vulnerability assessment and its application to Poland", in Fiscal policy, public debt and monetary policy in emerging market economies, BIS Papers n. 67.

Johnson, S. A., (1997), "An Empirical Analysis of the Determinants of Corporate Debt Ownership Structure", Journal of Financial and Quantitative Analysis, 32, pp. 47-69.

Johnson, S. A., (2003), "Debt Maturity and the Effects of Growth Opportunities and Liquidity Risk on Leverage", Review of Financial Studies, 16, pp. 209-236.

Lago-Peñas, S. (2005), "Evolving federations and regional public deficits: testing the bailout hypothesis in the Spanish case", Environment and Planning C: Government and Policy, 23, pp. 317-474. 
Leal Marcos, A. and J. López Laborda (2009), "Efectos externos del endeudamiento sobre la calificación crediticia de las Comunidades Autónomas", Hacienda Pública Española/Review of Public Economics, 189-(2/2009), pp. 81-106.

Lee, H. W., Y. A. Xie, and J. Yau (2011), "The impact of sovereign risk on bond duration: evidence from the Asian sovereign bond markets", International Review of Economics and Finance 20, pp. 441-451.

Leland H. E. and D.H. Pyle (1977), "Informational Asymmetries, Financial Structure, and Financial Intermediation", The Journal of Finance, Vol. 32, No. 2, Papers and Proceedings of the Thirty-Fifth Annual Meeting of the American Finance Association, Atlantic City, New Jersey, September 16-18, 1976 (May, 1977), pp. 371-387.

Mehl, A. and J. Reynaud (2010), "Risky public domestic debt composition in emerging economies", Journal of International Money and Finance, 29, pp. 1-18..

Missale, A. and O. J. Blanchard (1994), "The Debt Burden and Debt Maturity", The American Economic Review, 84, pp. 309-319.

Missale, A., F. Giavazzi, and P. Benigno (1997), "Managing the public debt in fiscal stabilizations: the evidence", NBER Working Paper 6311.

Moldogaziev, T. T. and M. J. Luby (2012), "State and Local Government Bond Refinancing and the Factors Associated with the Refunding Decision", Public Finance Review 40, pp. 614-642.

Myers, S. C., (1977), "Determinants of Corporate Borrowing", Journal of Financial Economics, 5, pp. 147-175.

Rodrick, D. and A. Velasco (1999), "Short-term capital flows", NBER Working Paper No 7364.

Roodman D. (2006), "How to Do xtabond2: An introduction to "Difference" and "System" GMM in Stata", Centre for Global Development, Working Paper Number 103. 
Romeu, R. (2013), "Improving regional fiscal discipline", pp. 18-22 in "Spain: 2013 Article IV Consultation. Selected Issues", International Monetary Fund, Washington.

Ross, S., (1977), "The Determination of Financial Structure - The Incentive Signalling Approach", Rand Journal of Economics, 8, pp. 23-41.

Stohs, M. H. and D. C. Mauer (1996), "The Determinants of Corporate Debt Maturity Structure", The Journal of Business, Vol. 69, No. 3, (Jul., 1996), pp. 279-312.

Sorribas-Navarro, P. (2011), "Bailouts in a fiscal federal system: evidence from Spain", European Journal of Political Economy, European Journal of Political Economy 27, pp. 154-170.

Valev, N. T. (2007), "Uncertainty and international debt maturity", International Financial Markets, Institutions and Money, 17, p. 372-386.

Valev, N. T. (2006), "Institutional uncertainty and the maturity of international loans", Journal of International Money and Finance, 25, p. 780-794.

van Hecke, A. (2013), "Vertical debt spillovers in EMU counriest", Journal of International Money and Finance, in press.

Vigneault, M. (2007), "Grants and the soft budget constraints", in Intergovernmental Fiscal Transfers: Principles and Practice, R. Boadway and A. Shah (Eds.). Washington DC: World Bank.

World Bank (2005), "Public Debt and Its Determinants in Market Access Countries". 
Figure 1: The evolution of General Government (EDP) debt and aggregate of Regional Governments' non-consolidated debt in Spain, 1990-2012.

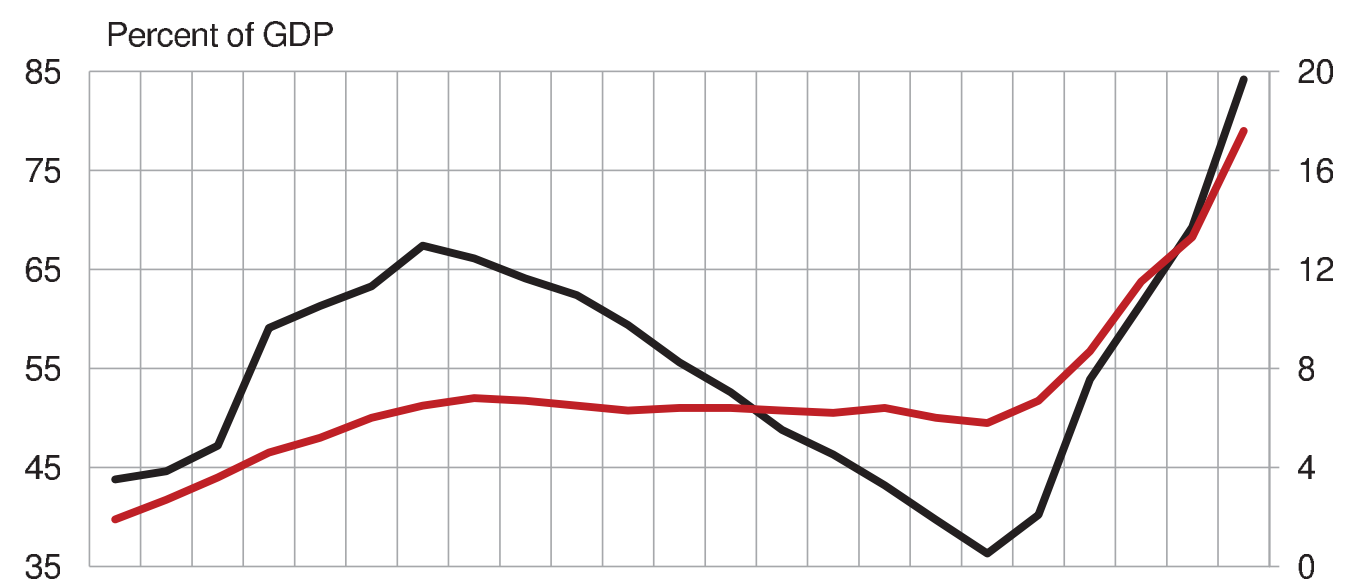

9091929394959697989900010203040506070809101112

- General Government (left axis) —Regional Governments (right axis) 
Table 1: The structure of regional governments' debt in Spain.

\begin{tabular}{|c|c|c|c|c|c|}
\hline & & 1995Q4 & 2007Q4 & $2011 Q 4$ & 2012Q4 \\
\hline Total debt ${ }^{a}$ as a percent of GDP & $B_{t} / Y_{t}$ & 6.0 & 5.8 & 13.3 & 17.6 \\
\hline of which Central Gov. support Funds & $B_{t}^{L, C G} / Y_{t}$ & - & - & - & 3.3 \\
\hline Total debt as a percent of total revenue & & 59.3 & 38.6 & 96.6 & 126.2 \\
\hline Long-term ${ }^{b}$ debt as $\%$ of long + short $^{b}$ & $B_{t}^{L T} /\left[B_{t}^{L T}+B_{t}^{S T}\right]$ & 75.2 & 90.1 & 81.1 & 87.4 \\
\hline Short-term ${ }^{b}$ debt as $\%$ of long + short $^{b}$ & $B_{t}^{S T} /\left[B_{t}^{L T}+B_{t}^{S T}\right]$ & 24.8 & 9.9 & 18.9 & 12.6 \\
\hline Short-term $^{b}$ as $\%$ of long-term ${ }^{b}$ debt & $B_{t}^{S T} / B_{t}^{L T}$ & 33.0 & 10.9 & 23.3 & 14.4 \\
\hline Securities as a percent of total debt & $\overline{B_{t}^{S} / B_{t}}$ & 39.7 & 51.4 & 44.9 & 34.5 \\
\hline Loans as a percent of total debt & $B_{t}^{L} / B_{t}$ & 60.3 & 48.6 & 55.1 & 65.5 \\
\hline of which Central Gov. support Funds & $B_{t}^{L, C G} / B_{t}$ & - & - & - & 18.6 \\
\hline Securities as \% of loans & $B_{t}^{S} / B_{t}^{L}$ & 65.8 & 105.9 & 81.4 & 52.7 \\
\hline excluding Central Gov. support Funds & $B_{t}^{S} /\left[B_{t}^{L}-B_{t}^{L, C G}\right]$ & - & - & - & 73.6 \\
\hline Loans by resident $\mathrm{FI}^{c}$ as $\%$ of total loans & $B_{t}^{R} / B_{t}^{L}$ & 80.2 & 47.4 & 59.5 & 44.1 \\
\hline excluding Central Gov. support Funds & $B_{t}^{R} /\left[B_{t}^{L}-B_{t}^{L, C G}\right]$ & - & - & - & 61.6 \\
\hline Loans non-residents ${ }^{d}$ as $\%$ of resident $\mathrm{FI}^{c}$ & $B_{t}^{N R} / B_{t}^{R}$ & 24.8 & 106.1 & 59.4 & 53.5 \\
\hline
\end{tabular}

Notes: ${ }^{a}$ Sum of Securities other than shares $\left(B_{t}^{S}\right)$ and Loans $\left(B_{t}^{L}\right)$. The breakdown of $B_{t}^{S}$ between Short-term and Long-term securities is available, but not the breakdown between resident and non-resident holders of Securities. $B_{t}^{L}$ is the sum of Resident Financial Institutions, Rest of the World, Central Government, and Public-private Partnerships. The breakdown of Loans by Resident Financial Institutions by short-term and long-term is available. ${ }^{b}$ Sum of Securities other than shares and Loans by Resident Financial Institutions. ${ }^{c}$ FI: Financial Institutions. ${ }^{d}$ Loans by the Rest of the World. 
Figure 2: The structure of regional governments' debt.

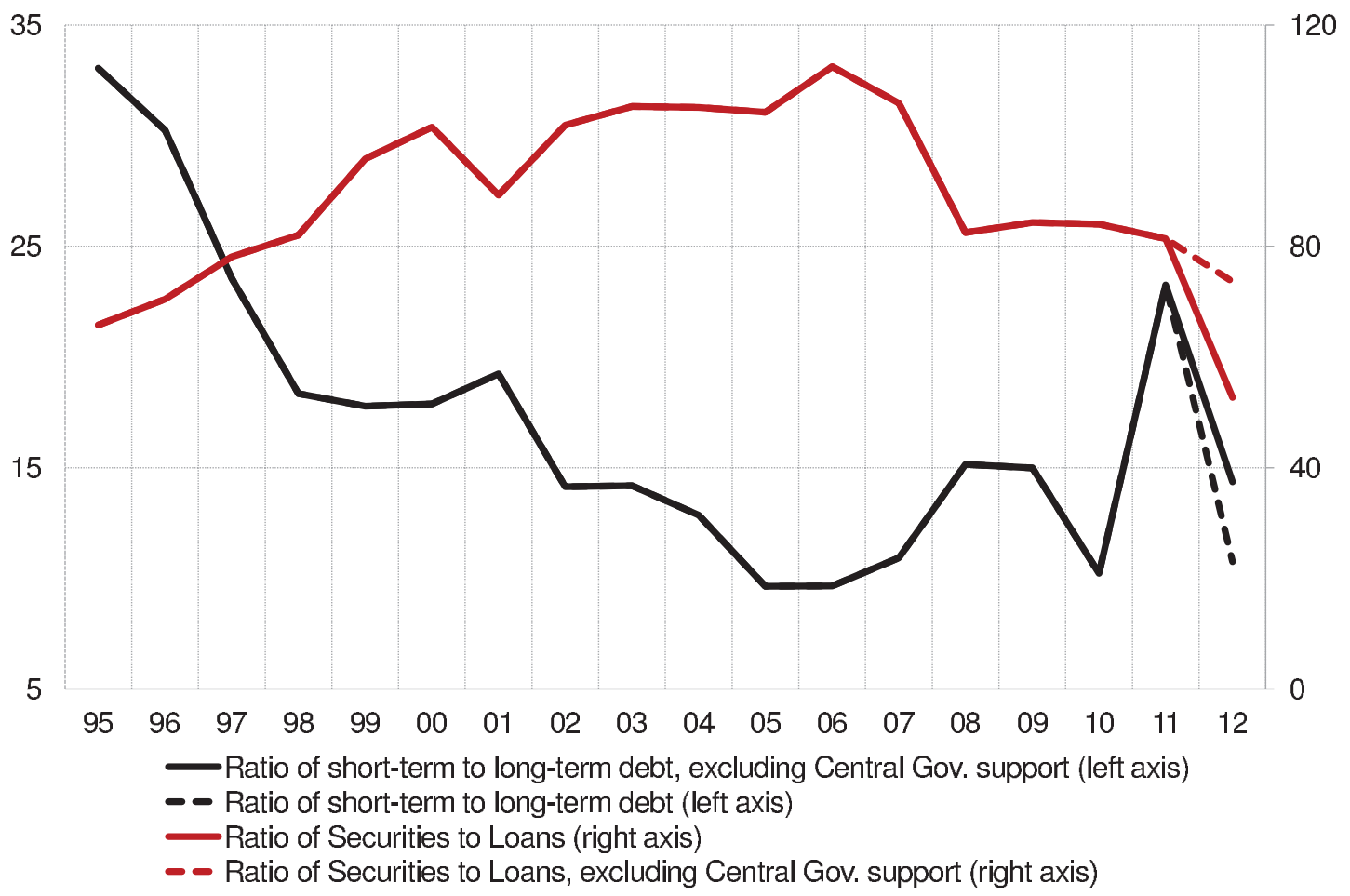


Figure 3: The structure of regional governments' debt: ratio short- to long-term $\operatorname{debt}^{a}$ versus financing needs (the size of the bubble measures the relative level of public debt as a percent of each region's GDP).
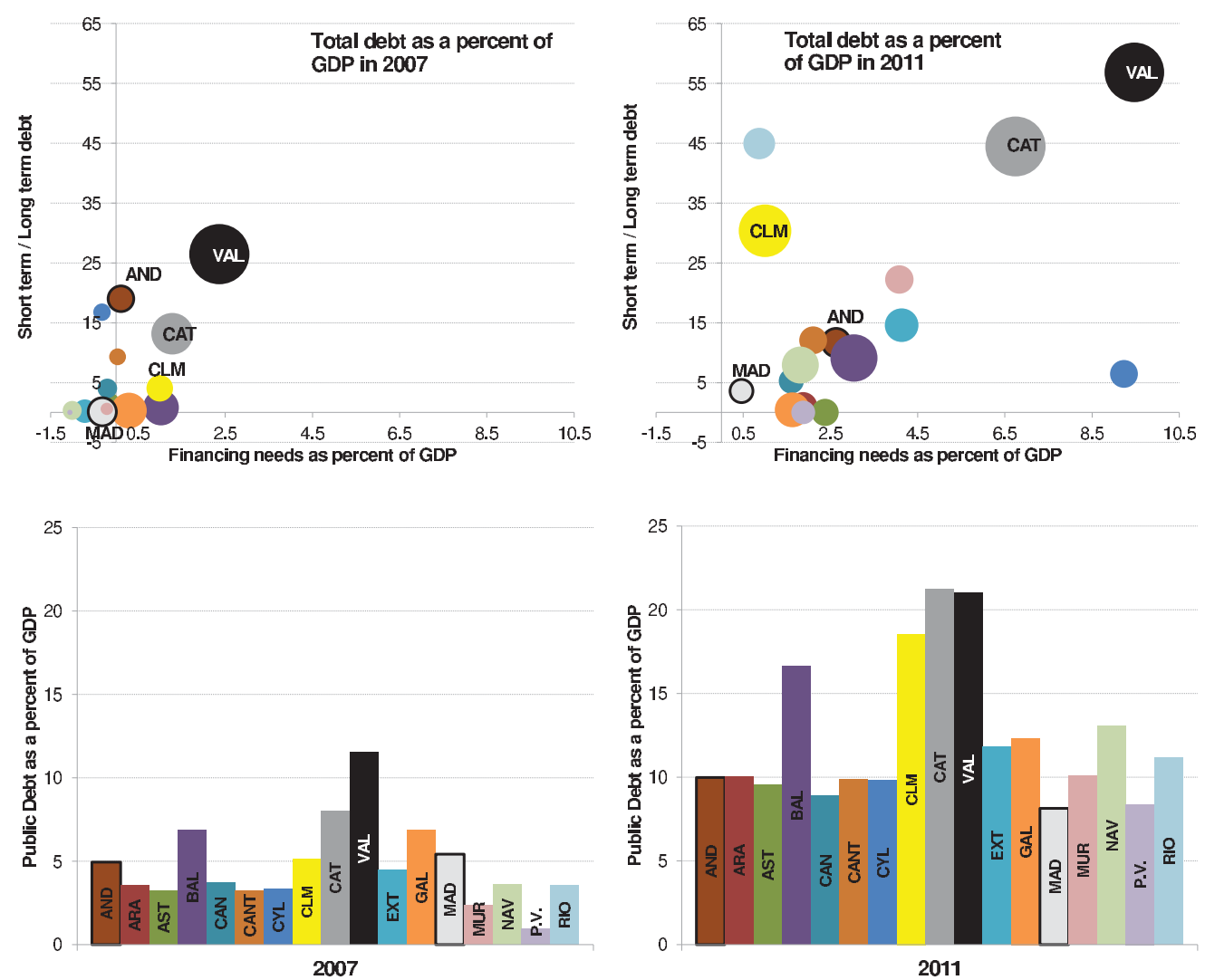

Notes: ${ }^{a}$ Short(long-)-term debt is the sum of short(long-)-term Securities and Loans by Resident Financial Institutions. The breakdown by maturity of the aggregates of loans by the "Rest of the World" and Loans by the "Central Government" are not available. AND: Andalusia; ARA: Aragon; AST: Asturias; BAL: Balearic Islands; CAN: Canary Islands; CANT: Cantabria; CYL: Castille and Leon; CLM: Castille- La Mancha; CAT: Catalonia; VAL: Valencia; EXT: Extremadura; GAL: Galicia; MAD: Madrid; MUR: Murcia; NAV:Navarre; PV: Basque Country; RIO: La Rioja. 
Figure 4: The Central Government support Funds ${ }^{a}$ to ease Regional Governments' liquidity troubles.

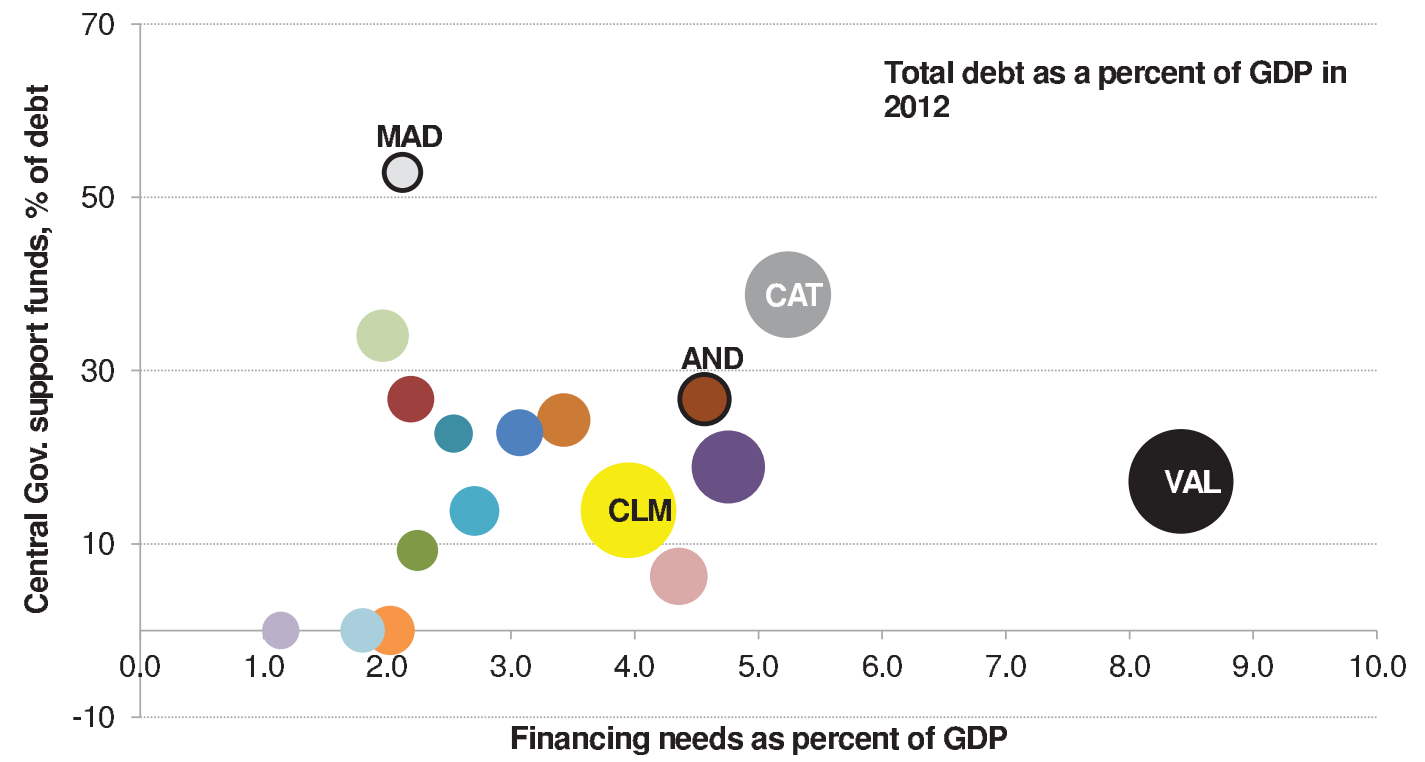

Notes: ${ }^{a}$ FLA: Fondo de Liquidez Autonómica (Regional Liquidity Fund), and FFPP: Fondo para la Financiación del Pago a los Proveedores (Fund for the Payment of Providers). See also footnote to Figure 3. 
Figure 5: Regional governments' debt: unconditional correlations between main debt structure indicators (annual data: 1995-2012).

Ratio of loans to securities vs

Ratio of short-run to long-run debt

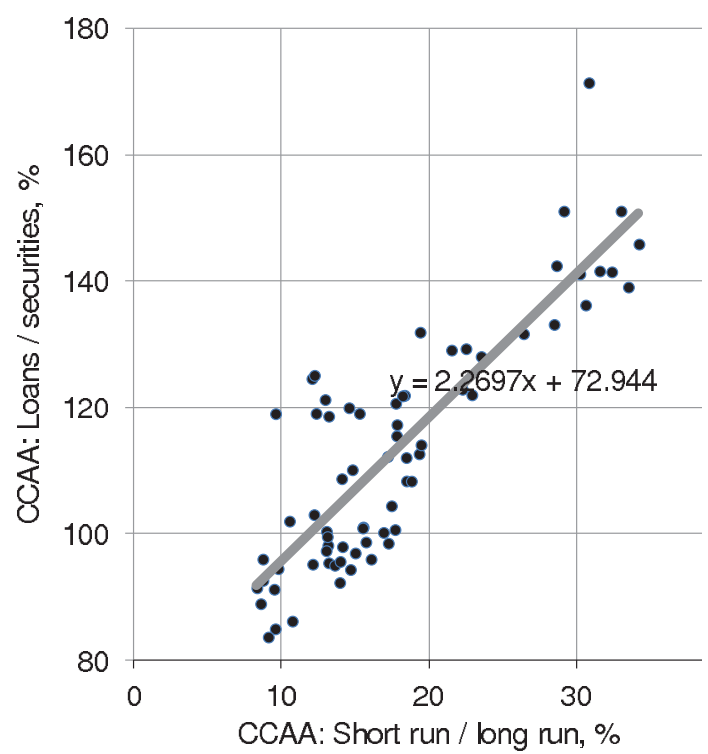

Ratio of loans to residents vs non residents vs Ratio of loans to securities

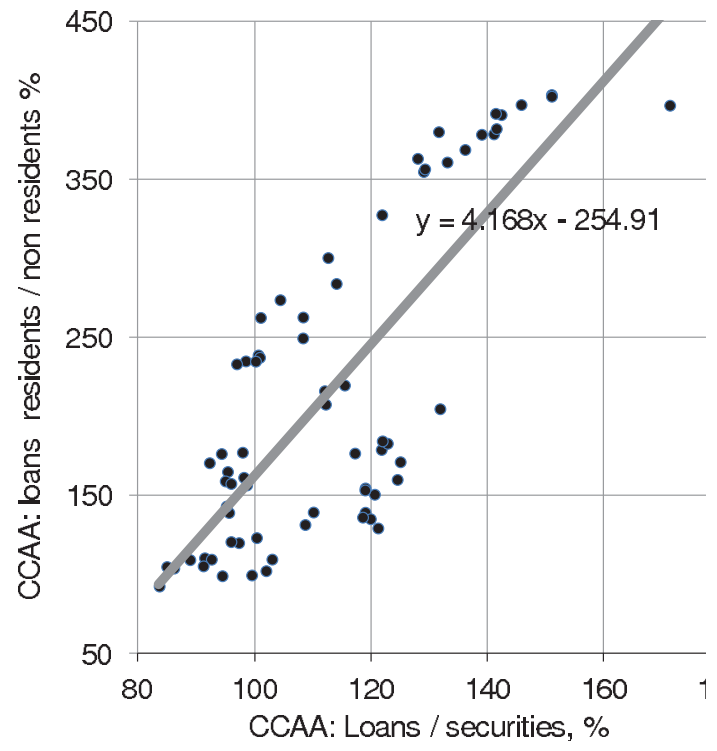

Ratio of loans to residents vs non residents vs

Ratio of short-run to long-run debt

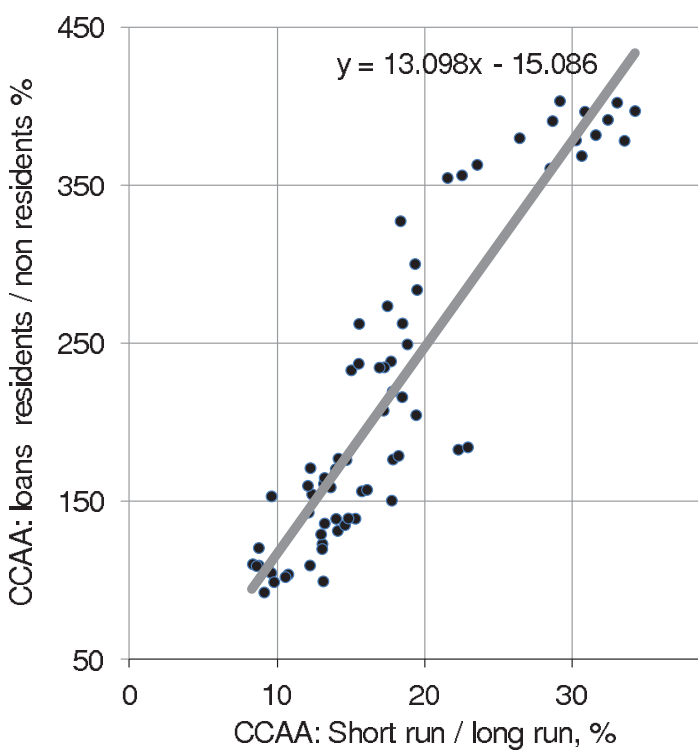

Implicit interest rate vs

Ratio of short-run to long-run debt

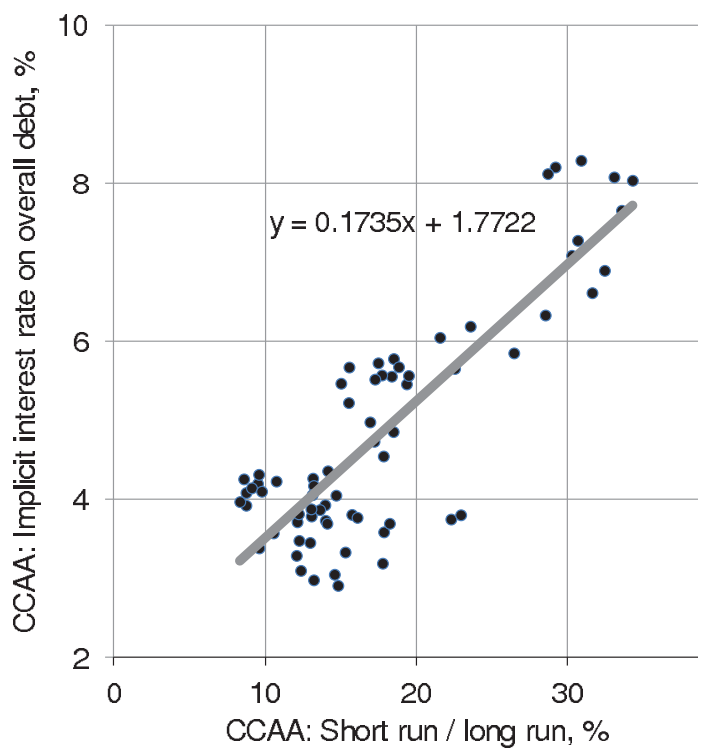


Table 2: The determinants of regional governments' debt structure: ratio of short- to longterm debt, $B_{t}^{S T} / B_{t}^{L T}$.

\begin{tabular}{l|ccccccc} 
& \multicolumn{7}{|c}{ Sample 1995Q1-2012Q4 } \\
& {$[1]$} & {$[2]$} & {$[3]$} & {$[4]$} & {$[5]$} & {$[6]$} & {$[6 \mathrm{~b}]$} \\
& & & & & & & OLS \\
\hline Lagged dependent variable & $0.46^{a}$ & $0.47^{a}$ & $0.46^{a}$ & $0.46^{a}$ & $0.47^{a}$ & $0.47^{a}$ & $0.76^{a}$ \\
Financing needs & $3.73^{a}$ & $3.89^{b}$ & $2.84^{b}$ & $2.64^{b}$ & $3.02^{b}$ & $3.02^{b}$ & $4.07^{a}$ \\
Cycle & -0.09 & -0.09 & -0.08 & & & & \\
Sustainability (S1) & 0.02 & & & & & & \\
Size & $0.86^{c}$ & $0.90^{b}$ & $1.02^{b}$ & $0.99^{c}$ & $1.05^{b}$ & $1.05^{b}$ & 0.07 \\
Budgetary deviation & $-2.94^{c}$ & -2.79 & -2.97 & -2.85 & $-3.51^{c}$ & $-3.51^{c}$ & 0.72 \\
Debt x Change in debt & -0.08 & -0.09 & & & & & \\
Debt deviation & -0.13 & -0.16 & & & & & \\
CG transfers, \% GDP & $-1.05^{c}$ & $-1.13^{c}$ & $-1.13^{c}$ & $-1.24^{b}$ & $-1.05^{b}$ & $-1.05^{b}$ & $-0.89^{b}$ \\
Slope & 0.24 & 0.42 & & 0.55 & & & \\
FRI & 0.32 & 0.35 & 0.37 & 0.37 & 0.31 & 0.31 & $0.34^{c}$ \\
Bonds coverage & $0.10^{b}$ & $0.09^{c}$ & $0.10^{c}$ & $0.10^{b}$ & $0.10^{c}$ & $0.10^{c}$ & 0.00 \\
NR/R preference & $-0.16^{c}$ & $-0.16^{c}$ & $-0.16^{c}$ & $-0.16^{c}$ & $-0.16^{c}$ & $-0.16^{c}$ & $-0.03^{b}$ \\
Elections dates & 1.71 & & & & & & \\
\hline Number of obs. & 1,088 & 1,088 & 1,088 & 1,088 & 1,088 & 1,088 & 1,088 \\
N. of Regions & 16 & 16 & 16 & 16 & 16 & 16 & \\
Hansen p-value & 1.000 & 0.998 & 0.917 & 0.809 & 0.702 & 0.702 & \\
AR1 p-value & 0.004 & 0.004 & 0.004 & 0.004 & 0.004 & 0.004 & \\
AR2 p-value & 0.290 & 0.293 & 0.284 & 0.287 & 0.287 & 0.287 & \\
F p-value & 0 & 0 & 0 & 0 & 0 & 0 & \\
\hline
\end{tabular}

${ }^{a},{ }^{b},{ }^{c}$ : significance at the $1 \%, 5 \%$ and $10 \%$ levels. Instruments: regressors used in each specification. 
Table 3: The determinants of regional governments' debt structure: ratio of short- to longterm debt, $B_{t}^{S T} / B_{t}^{L T}$ (continued).

\begin{tabular}{l|ccc|ccc|ccc} 
& \multicolumn{3}{|c}{$1995 \mathrm{Q} 1-2012 \mathrm{Q} 4$} & \multicolumn{3}{c}{ 1995Q1-2011Q4 } & \multicolumn{3}{c}{$1995 \mathrm{Q} 1-2007 \mathrm{Q} 4$} \\
& {$[7]$} & {$[8]$} & {$[8 \mathrm{~b}]$} & {$[9]$} & {$[10]$} & {$[10 \mathrm{~b}]$} & {$[11]$} & {$[12]$} & {$[12 \mathrm{~b}]$} \\
& & & OLS & & & OLS & & & OLS \\
\hline Lagged dep. variable & $0.46^{a}$ & $0.47^{a}$ & $0.76^{a}$ & $0.46^{a}$ & $0.48^{a}$ & $0.75^{a}$ & $0.52^{a}$ & $0.56^{a}$ & $0.74^{a}$ \\
Financing needs & $3.73^{a}$ & $3.02^{b}$ & $4.07^{a}$ & $6.80^{a}$ & $6.07^{a}$ & $4.91^{a}$ & $7.13^{a}$ & $10.01^{a}$ & $7.68^{a}$ \\
Cycle & -0.09 & & & 0.02 & & & -0.05 & & \\
Sustainability (S1) & 0.02 & & & -0.60 & & & 3.25 & & \\
Size & $0.86^{c}$ & $1.05^{b}$ & 0.07 & $0.97^{b}$ & $1.30^{b}$ & 0.07 & $0.67^{c}$ & $0.56^{c}$ & 0.06 \\
Budgetary deviation & $-2.94^{c}$ & $-3.51^{c}$ & 0.72 & -7.71 & $-8.75^{c}$ & -0.86 & -5.40 & -10.08 & -2.89 \\
Debt x Change in debt & -0.08 & & & -0.27 & & & -0.94 & & \\
Debt deviation & -0.13 & & & 0.12 & & & -0.10 & & \\
CG transfers, \% GDP & $-1.05^{c}$ & $-1.05^{b}$ & $-0.89^{b}$ & -1.15 & -1.32 & $-0.90^{c}$ & -0.49 & $-1.41^{c}$ & -0.32 \\
Slope & 0.24 & & & -0.03 & & & 0.34 & & \\
FRI & 0.32 & 0.31 & $0.34^{c}$ & 0.33 & 0.33 & 0.35 & 0.22 & 0.55 & 0.15 \\
Bonds coverage & $0.10^{b}$ & $0.10^{c}$ & 0.00 & $0.10^{c}$ & 0.09 & -0.00 & $0.11^{a}$ & $0.10^{b}$ & 0.02 \\
NR/R preference & $-0.16^{c}$ & $-0.16^{c}$ & $-0.03^{b}$ & $-0.16^{c}$ & $-0.16^{c}$ & $-0.03^{a}$ & -0.12 & -0.12 & $-0.03^{a}$ \\
Elections dates & 1.71 & & & 1.86 & & & 3.27 & & \\
\hline Number of obs. & 1,088 & 1,088 & 1,088 & 1,024 & 1,024 & & 768 & 768 & \\
N. of Regions & 16 & 16 & & 16 & 16 & & 16 & 16 & \\
Hansen p-value & 1.000 & 0.702 & & 1.000 & 0.794 & & 1 & 0.694 & \\
AR1 p-value & 0.004 & 0.004 & & 0.005 & 0.005 & & 0.017 & 0.013 & \\
AR2 p-value & 0.290 & 0.287 & & 0.294 & 0.296 & & 0.316 & 0.262 & \\
F p-value & 0 & 0 & & 0 & 0 & & 0 & 0 & \\
\hline
\end{tabular}

$a, b,{ }^{c}$ : significance at the $1 \%, 5 \%$ and $10 \%$ levels. Instruments: regressors used in each specification. 
Table 4: The determinants of regional governments' debt structure: ratio of Securities to Loans, $B_{t}^{S} /\left[B_{t}^{L}-B_{t}^{C G, L}\right]$.

\begin{tabular}{l|ccc|ccc|ccc} 
& \multicolumn{3}{|c}{$1995 \mathrm{Q} 1-2012 \mathrm{Q} 4$} & \multicolumn{3}{c}{$1995 \mathrm{Q} 1-2011 \mathrm{Q} 4$} & \multicolumn{2}{c}{$1995 \mathrm{Q} 1-2007 \mathrm{Q} 4$} \\
& {$[1]$} & {$[2]$} & {$[2 \mathrm{~b}]$} & {$[3]$} & {$[4]$} & {$[4 \mathrm{~b}]$} & {$[5]$} & {$[6]$} & {$[6 \mathrm{~b}]$} \\
& & & OLS & & & OLS & & & OLS \\
\hline Lag. dep. var. & $0.65^{a}$ & $0.66^{a}$ & $0.90^{a}$ & $0.67^{a}$ & $0.66^{a}$ & $0.90^{a}$ & $0.66^{a}$ & $0.64^{a}$ & $0.94^{a}$ \\
Financing needs & $-26.27^{a}$ & $-26.61^{a}$ & $-7.58^{a}$ & $-32.28^{b}$ & $-24.61^{b}$ & $-7.84^{a}$ & $-63.70^{b}$ & $-59.28^{a}$ & $-18.18^{a}$ \\
Cycle & 0.24 & & & 0.23 & & & 0.13 & & \\
Sustainability & -1.69 & & & -2.72 & & & -4.39 & & \\
Size & 0.92 & -0.28 & 0.34 & 1.38 & -0.24 & 0.31 & 2.45 & 3.67 & $0.33^{b}$ \\
Budgetary dev. & 7.82 & 6.32 & -3.46 & 2.43 & $18.21^{b}$ & -5.66 & 22.38 & 18.15 & $-20.35^{c}$ \\
Debt x $\Delta$ debt & $-0.68^{b}$ & & & $-0.91^{b}$ & & & $-1.49^{b}$ & & \\
Debt deviation & 1.87 & & & 4.02 & & & 6.29 & & \\
CG transfers & $3.31^{b}$ & $4.00^{b}$ & -0.57 & $4.43^{c}$ & $5.43^{b}$ & -1.20 & 6.39 & 4.98 & 0.22 \\
Slope & -2.02 & & & -1.65 & & & 3.57 & & \\
FRI & -0.29 & -0.56 & 0.20 & -0.89 & $-1.40^{c}$ & 0.46 & -1.87 & -1.57 & -0.17 \\
Bonds coverage & 0.28 & 0.30 & 0.01 & 0.24 & 0.31 & 0.02 & 0.03 & 0.04 & 0.06 \\
NR/R pref. & $0.57^{a}$ & $0.58^{a}$ & 0.11 & $0.57^{a}$ & $0.60^{a}$ & 0.11 & $0.55^{b}$ & $0.61^{a}$ & 0.08 \\
Elections dates & -2.37 & & & $-4.01^{b}$ & & & -5.14 & & \\
\hline Number of obs. & 1,088 & 1,088 & 1,088 & 1,024 & 1,024 & 1,088 & 768 & 768 & \\
N. of Regions & 16 & 16 & & 16 & 16 & & 16 & 16 & \\
Hansen p-value & 1.000 & 0.799 & & 1.000 & 0.857 & & 1.000 & 0.928 & \\
AR1 p-value & 0.259 & 0.270 & & 0.257 & 0.272 & & 0.108 & 0.144 & \\
AR2 p-value & 0.284 & 0.294 & & 0.280 & 0.294 & & 0.205 & 0.242 & \\
F p-value & 0 & 0 & & 0 & 0 & & 0 & 0 & \\
\hline
\end{tabular}

${ }^{a},{ }^{b},{ }^{c}$ : significance at the $1 \%, 5 \%$ and $10 \%$ levels. Instruments: regressors used in each specification. 
Table 5: The determinants of regional governments' debt structure: robustness test for the number of lags used as instruments. Selected results (estimation period: 1995Q1-2012Q4).

\begin{tabular}{l|cccc|cccc} 
& \multicolumn{7}{|c|}{ Ratio of short- to long-term debt } & \multicolumn{5}{|c}{ Ratio of Securities to Loans } \\
& 1 lag & 2 lags & 3 lags & OLS & 1 lag & 2 lags & 3 lags & OLS \\
& & & & & & & & \\
\hline Lagged dep. variable & $0.64^{a}$ & $0.47^{a}$ & $0.46^{a}$ & $0.76^{a}$ & $0.55^{a}$ & $0.66^{a}$ & $0.60^{a}$ & $0.90^{a}$ \\
Financing needs & 1.56 & $3.02^{b}$ & $3.71^{a}$ & $4.07^{a}$ & $-56.41^{a}$ & $-26.61^{a}$ & $-62.75^{b}$ & $-7.58^{a}$ \\
Size & 0.98 & $1.05^{b}$ & $1.02^{c}$ & 0.07 & 3.76 & -0.28 & 3.27 & 0.34 \\
Budgetary deviation & -3.04 & $-3.51^{c}$ & -2.76 & 0.72 & 14.47 & 6.32 & 49.31 & -3.46 \\
CG transfers,\%GDP & $-0.88^{b}$ & $-1.05^{b}$ & $-0.86^{c}$ & $-0.89^{b}$ & 6.44 & $4.00^{b}$ & 7.97 & -0.57 \\
FRI & 0.23 & 0.31 & 0.12 & $0.34^{c}$ & -1.77 & -0.56 & -3.02 & 0.20 \\
Bonds coverage & 0.05 & $0.10^{c}$ & $0.13^{b}$ & 0.00 & 0.03 & 0.30 & 0.15 & 0.01 \\
NR/R preference & $-0.18^{c}$ & $-0.16^{c}$ & $-0.16^{c}$ & $-0.03^{a}$ & $0.63^{a}$ & $0.58^{a}$ & $0.52^{b}$ & 0.11 \\
\hline Number of obs. & 1,088 & 1,088 & 1,088 & & 768 & 1,088 & 768 & \\
N. of Regions & 16 & 16 & 16 & & 16 & 16 & 16 & \\
Hansen p-value & 0.199 & 0.702 & 0.991 & & 0.161 & 0.799 & 0.938 & \\
AR1 p-value & 0.0187 & 0.00365 & 0.00408 & & 0.125 & 0.270 & 0.128 & \\
AR2 p-value & 0.303 & 0.287 & 0.292 & & 0.232 & 0.294 & 0.225 & \\
F p-value & 0 & 0 & 0 & & 0 & 0 & 0 & \\
\hline
\end{tabular}

${ }^{a},{ }^{b},{ }^{c}$ : significance at the $1 \%, 5 \%$ and $10 \%$ levels. Instruments: regressors used in each specification. 


\title{
BANCO DE ESPAÑA PUBLICATIONS
}

\author{
WORKING PAPERS
}

1220 ENRIQUE ALBEROLA, LUIS MOLINA and PEDRO DEL RÍO: Boom-bust cycles, imbalances and discipline in Europe.

1221 CARLOS GONZÁLEZ-AGUADO and ENRIQUE MORAL-BENITO: Determinants of corporate default: a BMA approach.

1222 GALO NUÑO and CARLOS THOMAS: Bank leverage cycles.

1223 YUNUS AKSOY and HENRIQUE S. BASSO: Liquidity, term spreads and monetary policy.

1224 FRANCISCO DE CASTRO and DANIEL GARROTE: The effects of fiscal shocks on the exchange rate in the EMU and differences with the US.

1225 STÉPHANE BONHOMME and LAURA HOSPIDO: The cycle of earnings inequality: evidence from Spanish social security data.

1226 CARMEN BROTO: The effectiveness of forex interventions in four Latin American countries.

1227 LORENZO RICCI and DAVID VEREDAS: TailCoR.

1228 YVES DOMINICY, SIEGFRIED HÖRMANN, HIROAKI OGATA and DAVID VEREDAS: Marginal quantiles for stationary processes.

1229 MATTEO BARIGOZZI, ROXANA HALBLEIB and DAVID VEREDAS: Which model to match?

1230 MATTEO LUCIANI and DAVID VEREDAS: A model for vast panels of volatilities.

1231 AITOR ERCE: Does the IMF's official support affect sovereign bond maturities?

1232 JAVIER MENCÍA and ENRIQUE SENTANA: Valuation of VIX derivatives.

1233 ROSSANA MEROLA and JAVIER J. PÉREZ: Fiscal forecast errors: governments vs independent agencies?

1234 MIGUEL GARCÍA-POSADA and JUAN S. MORA-SANGUINETTI: Why do Spanish firms rarely use the bankruptcy system? The role of the mortgage institution.

1235 MAXIMO CAMACHO, YULIYA LOVCHA and GABRIEL PEREZ-QUIROS: Can we use seasonally adjusted indicators in dynamic factor models?

1236 JENS HAGENDORFF, MARÍA J. NIETO and LARRY D. WALL: The safety and soundness effects of bank M\&As in the EU: Does prudential regulation have any impact?

1237 SOFÍA GALÁN and SERGIO PUENTE: Minimum wages: do they really hurt young people?

1238 CRISTIANO CANTORE, FILIPPO FERRONI and MIGUEL A. LEÓN-LEDESMA: The dynamics of hours worked and technology.

1239 ALFREDO MARTÍN-OLIVER, SONIA RUANO and VICENTE SALAS-FUMÁS: Why did high productivity growth of banks precede the financial crisis?

1240 MARIA DOLORES GADEA RIVAS and GABRIEL PEREZ-QUIROS: The failure to predict the Great Recession. The failure of academic economics? A view focusing on the role of credit.

1241 MATTEO CICCARELLI, EVA ORTEGA and MARIA TERESA VALDERRAMA: Heterogeneity and cross-country spillovers in macroeconomic-financial linkages.

1242 GIANCARLO CORSETTI, LUCA DEDOLA and FRANCESCA VIANI: Traded and nontraded goods prices, and international risk sharing: an empirical investigation.

1243 ENRIQUE MORAL-BENITO: Growth empirics in panel data under model uncertainty and weak exogeneity.

1301 JAMES COSTAIN and ANTON NAKOV: Logit price dynamics.

1302 MIGUEL GARCÍA-POSADA: Insolvency institutions and efficiency: the Spanish case.

1303 MIGUEL GARCÍA-POSADA and JUAN S. MORA-SANGUINETTI: Firm size and judicial efficacy: evidence for the new civil procedures in Spain.

1304 MAXIMO CAMACHO and GABRIEL PEREZ-QUIROS: Commodity prices and the business cycle in Latin America: living and dying by commodities?

1305 CARLOS PÉREZ MONTES: Estimation of regulatory credit risk models.

1306 FERNANDO LÓPEZ VICENTE: The effect of foreclosure regulation: evidence for the US mortgage market at state level.

1307 ENRIQUE MORAL-BENITO and LUIS SERVEN: Testing weak exogeneity in cointegrated panels.

1308 EMMA BERENGUER, RICARDO GIMENO and JUAN M. NAVE: Term structure estimation, liquidity-induced heteroskedasticity and the price of liquidity risk.

1309 PABLO HERNÁNDEZ DE COS and ENRIQUE MORAL-BENITO: Fiscal multipliers in turbulent times: the case of Spain. 
1310 SAMUEL HURTADO: DSGE models and the Lucas critique.

1311 HENRIQUE S. BASSO and JAMES COSTAIN: Fiscal delegation in a monetary union with decentralized public spending.

1312 MAITE BLÁZQUEZ CUESTA and SANTIAGO BUDRÍA: Does income deprivation affect people's mental well-being?

1313 ENRIQUE ALBEROLA, ÁNGEL ESTRADA and DANIEL SANTABÁRBARA: Growth beyond imbalances. Sustainable growth rates and output gap reassessment.

1314 CARMEN BROTO and GABRIEL PEREZ-QUIROS: Disentangling contagion among sovereign CDS spreads during the European debt crisis.

1315 MIGUEL GARCÍA-POSADA and JUAN S. MORA-SANGUINETTI: Are there alternatives to bankruptcy? A study of small business distress in Spain.

1316 ROBERTO RAMOS and ENRIQUE MORAL-BENITO: Agglomeration matters for trade.

1317 LAURA HOSPIDO and GEMA ZAMARRO: Retirement patterns of couples in Europe.

1318 MAXIMO CAMACHO, GABRIEL PEREZ-QUIROS and PILAR PONCELA: Short-term forecasting for empirical economists. A survey of the recently proposed algorithms.

1319 CARLOS PÉREZ MONTES: The impact of interbank and public debt markets on the competition for bank deposits.

1320 OLYMPIA BOVER, JOSE MARIA CASADO, SONIA COSTA, PHILIP DU CAJU, YVONNE MCCARTHY, EVA SIERMINSKA, PANAGIOTA TZAMOURANI, ERNESTO VILLANUEVA and TIBOR ZAVADIL: The distribution of debt across euro area countries: the role of Individual characteristics, institutions and credit conditions.

1321 BRINDUSA ANGHEL, SARA DE LA RICA and AITOR LACUESTA: Employment polarisation in Spain over the course of the 1997-2012 cycle.

1322 RODOLFO G. CAMPOS and ILIANA REGGIO: Measurement error in imputation procedures.

1323 PABLO BURRIEL and MARÍA ISABEL GARCÍA-BELMONTE: Meeting our D€STINY. A Disaggregated €uro area Short Term INdicator model to forecast GDP $(Y)$ growth.

1401 TERESA SASTRE and FRANCESCA VIANI: Countries' safety and competitiveness, and the estimation of current account misalignments.

1402 FERNANDO BRONER, ALBERTO MARTIN, AITOR ERCE and JAUME VENTURA: Sovereign debt markets in turbulent times: creditor discrimination and crowding-out effects.

1403 JAVIER J. PÉREZ and ROCíO PRIETO: The structure of sub-national public debt: liquidity vs credit risks.

\section{BANCODEESPAÑA}

Eurosistema
Unidad de Servicios Auxiliares

Alcalá, 48 - 28014 Madrid

E-mail: publicaciones@bde.es www.bde.es 